\title{
Promoting Student Academic Success: Paying Attention To Learning Environmental Factors
}

\author{
Nan Li, Ph.D., Claflin University, USA
}

\begin{abstract}
Achievement gaps become greater for schools with high-poverty and high-minority school population in the United States in recent years (Dillon, 2005; Lee \& Slaughter-Defoe, 2004). The academic success of minority students is important because the nation cannot successfully compete in a global market when a considerable portion of its school population is undereducated. This study examines the academic success of African-American pre-service teachers. Analyzed qualitative data reveals that to promote academic success of minority students, nurturing successful personal factors through supportive learning environments is important. In the light of the study findings, suggestions are provided for teachers to assure student academic success.
\end{abstract}

Keywords: Academic Success; Achievement Gap; Minority Students; Pre-Service Teachers; Supportive Learning Environments

\section{INTRODUCTION}

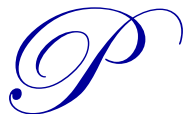

ublic schools across the nation continue to struggle with persistent achievement gaps (Lee \& Slaughter-Defoe, 2004; Li, 2005; Valentine, 2005). Data reveals that achievement gaps are persistent and minority students have lower literacy scores, i.e., one in four Hispanic teens and one in five African-American teens respectively read below the basic reading levels (Chiu \& Khoo, 2005; Darling-Hammond, 2004; NAEP, 2005). Yet, the academic success of minority students is important. School demographics are rapidly changing and today's school minority will soon be the majority. It is projected that by 2050 , over 50 percent of the U.S. population will be African-American, Hispanic, or Asian (U.S. Census Bureau, 2006). A nation cannot afford to fail the academic success of the future-majority school population. The purpose of this study was to identify the factors that promote academic success in minority students. Qualitative surveys and interviews were collected from two groups of pre-service teachers at an HBCU (Historically Black College \& University) in a two-year period. Data revealed that supportive learning environments play a significant role in student academic success.

Academic success is generally measured by two aspects. Cognitive measure includes mental ability and non-cognitive measure includes certain personality traits. High school grades, ACT scores, SAT scores or collegiate cumulative grade-point-average are often cognitive predictors (Ridgell \& Lounsbury, 2004). For non-cognitive measures, Barrick and Mount's (1993) seminal work establishes the foundation, i.e., the taxonomy of personality traits (i.e., conscientiousness, agreeableness, extraversion, emotional stability, and openness to experience). Studies show that non-cognitive factors are equally important for student academic success and successful students usually maintain a balance between the social and academic aspects of school, expect to succeed, and are socially proficient, goal oriented, and intrinsically motivated (Scheuermann, 2000). Teachers must cognize of nurturing these positive personal factors through supportive environment for minority student academic success. 


\section{METHODOLOGY}

Using qualitative research methods, this study examines two groups of pre-service teachers enrolled in the teacher education programs at an institution of higher learning, specifically a HBCU institution (Historically Black College and University). These two groups were candidate participants, who passed Praxis I, and non-candidate participants, who had not passed their Praxis I, in order to compare the factors for their academic efforts between the groups. The focus was on their current and past learning experiences. Accredited by the National Council of Accreditation for Teacher Education, the teacher education programs at this HBCU institution are intended to provide the quality services for all the pre-service teachers. Yet, passing Praxis I testing is a gauge, because it decides if an enrolled student will remain in the teacher education programs. Therefore, the study is important for the university and other institutions of higher learning with more minority student population.

\section{Data Collection \& Analysis}

In qualitative studies, the researcher depends upon interpretation involving intensive field participation, rich data collected in the field, and the researcher is the primary synthesizing and interpretive agent of data analysis (Patton, 2002). As a research procedure, the 4-page descriptive survey data was collected. Based on survey, interview was also conducted. Based on Merriam's (2001) effective data collection strategies, qualitative survey and interview questions both focused on three areas: 1) Life History-Past Learning, seeking factors from the students' past learning experiences that might affect their current learning; 2) Present Learning, examining the students' current learning experiences; and 3) Reflection on Meaning, interpreting how the participants felt about their learning experiences. Each of these areas contained five questions (see Figure 1).

\section{Figure 1: Survey and Interview Guide:}

Questions to Pre-Service Teacher Participants

A. Focus on Life History-Past Learning*

1. Where did you go to school? What was your school like?

- Elementary:

- High school:

2. How did most of your peers feel about their learning in your school?

3. How would you rate your teachers generally if using a ten scale?

4. What was your ordinary school day like?

5. Describe either a difficult or a successful school experience.

\section{B. Focus on Present-Current Learning*}

1. What is your ordinary day at university like?

2. What is your ordinary day at home like?

3. What is the highest educational degree of your father? Mother? Guardian?

4. What role do they play in your learning?

5. Describe a most difficult or successful current learning experience.

\section{Reflection on Meaning*}

1. What factors contribute to your success as a future teacher educator? What factors prevent your success as a future teacher educator?

2. What is your greatest assess to be successful?

3. What is your greatest weakness as a future teacher educator?

4. When faced with a difficult situation, how do you manage it? Please give an example.

5. How important is your current degree study? What is your long term goal?

*Source: Merriam, S. B. (2001). Conducting effective interviews. Qualitative research and case study application in education. (pp. 71-93). San Francisco, CA: Jossey-Bass Publishers.

Patterns emerged after the data analysis. The first category of questions focused the participants' past learning experiences of the participants. More positive responses were generally found from candidate participants. Conversely, the responses from non-candidate participants were usually negative. One of the survey questions asked, "What was your school like?" The following are some positive words from candidate participants: 
These were optimistic, energetic teachers; good teacher-student relation; school has a very good reputation for academics \& sports; I was one of the few...in the honors classes; The standard of education was very high and they prided themselves with a high overall student grade average; This was the time when I enjoyed going to school the most...

The responses from non-candidate participants were general more negative. The following are some sample words from non-candidate participants:

This school was full of violence and drugs; You had to take it upon yourself to do the right thing and study; this was not a very good educational environment because of slack enforcement of rules; it was a small, boring, predominately black school; I enjoyed my years at the school though I felt their [a grammar error] were too many restrictions...

The second category of questions asked the participants about their current learning experiences. Similarly, the responses of the groups were also significantly different. As the sample responses to one of the questions in this category that ask, "What is your ordinary day at university like?" Data indicated that most candidate participants were more organized in daily activities on campus and at home and then also maintained a hard work ethics. The following is such response from a candidate participant:

On an ordinary day last semester, I would get up in time for breakfast and get to my 10 a.m. course. After the 10, was an 11 a.m. class, then a break for lunch. I had a 2, 3, and 4 p.m. class as well. I would have dinner at 5 p.m. and rest for a while until $6 \mathrm{pm}$. At 6 I would juggle the various organization meetings that I was involved in. From 7-10 p.m. I would be working as an English tutor and from 10:30 to $12 \mathrm{pm}$ I would be working on music either in the dorm or in the auditorium. My day would end around 2 a.m., which was when I would complete studies for the next day and had a little time to relax...

Conversely, the responses from the non-candidate participants to the same question did not reveal organized daily schedules or hard-work ethic. More grammatical and spelling errors as well as lesser educational backgrounds of parents were noted in the responses of non-candidate participants to one of questions that asked: "What is the highest educational degree of your father? Mother? Guardian?" Candidate participants also perceived their academic learning as a challenge and worked hard to achieve academic success. Conversely, non-candidate participants had lower expectations and considered a simple tasks as academic success, e.g., a course assignment, when both groups were asked to describe "a most difficult or successful current learning experience."

For example, the following is some sample responses from non-candidate participants to the question that asked about their ordinary day at university:

My ordinary day at the university would be to go all my classes, get whatever important worth their [error for 'there'] was to be done, study if necessary, and hang out with my friends and associates; a university day is fun learning experience; a peaceful day spent hanging with my friends; my day at the university is like a train always on the go...

The third category of questions was designed to interpret how the participants felt about their learning. Question one in this category asked, "What factors contribute to your success as a future teacher? What factors prevent your success as a future teacher educator?" Data revealed differences between the two groups. Determination, hard work, self-motivation, eagerness to learn, and the presence of a support system from the family were central in the responses of many candidate participants. The responses from non-candidate participants in this category were not consistent so that a generalized pattern could not be identified. The question in the third category also asked the participants to respond on their weaknesses that prevented their success. In general, candidate participants demonstrated a higher level of reasoning skills in seeking the weaknesses and they were also more determined to overcome their weaknesses. Yet, non-candidate participants tended to focus on a lower level of thinking, e.g., some even considered disciplinary issues as the weakness. 
For example, the following are sample responses from the candidate participants regarding the question that asked about contributing factors to their success as a future teacher:

My family background contributes to my success as a teacher education candidate. Stress and peer pressure prevent my success; I don't feel that I've fully developed the leadership skills needed to be a teacher; Procrastination prevents my success; When I care too much, that creates self-doubt because I always want to make sure I'm doing the best...

The responses from non-candidate participants to the same question were not consistent so that it is difficult to generalize a pattern or themes from these responses. Yet, generally, it indicates that they were dealing with the lower level of expectations and behaviors:

My greatest weakness may be children's behavior, or my low tolerance level, and tests; Being on time to class; A weakness is not being able to handle situation; Factors that would prevent me would be taking the Praxis and continuing at the university to get in all the classes to become a teacher; My greatest weakness as a future teacher educator would be making things - activity projects.

In summary, to improve the minority students' learning, both cognitive and non-cognitive factors must be considered. Yet, to establish a supportive learning climate is important for enhancing confidence, self-esteem, and persistence in students. These personal factors support minority students to pursue learning despite challenges

\section{DISCUSSION \& CONCLUSION}

This study examines the factors of minority student academic success. Specifically, the study examines the factors of academic success in two groups of pre-service teachers at a HBCU institution. Qualitative survey and interview data were collected and analyzed. The components that were found as most important contributing factors for the academic success of the candidate participants were supportive learning environments and their proactive personal traits. Supportive learning environments not only included the climate at the schools and homes to support their physical learning but also including the ones that nurtured these students' confidence and persistence for achieving success. Minority students from the dominated cultures are more likely to stay in school due to teacher authority and yet they may be engaged in a struggle against norms (Campbell, 2004; Gollnick \& Chinn, 2005). Therefore, establishing supportive learning environments is the first step. Significantly, good teachers inspire students, model positive character traits through supportive environments in order to build resiliency in students to meet challenges for achieving academic success.

\section{SUGGESTIONS}

To improve the minority students' learning, both cognitive and non-cognitive factors are important and must be considered. Establishing a supportive learning climate can enhance confidence, self-esteem, and persistence in students. These personal factors for success will motivate and encourage minority students to pursue learning despite facing any difficulties. In light of the study findings, the following Four Build Strategies are provided for teachers to consider ensuring student academic success.

- $\quad$ First is to build confidence in students through supportive environment. Confidence is the foundation and teachers can build confidence by giving small-step tasks to help students gain successful feeling and experiences. Maslow's (1987) needs theory helps interpret human relations in classrooms. Therefore, students must also feel belonged to the learning community through positive feedback from teachers and supportive school climate. Teachers can positively engage students in an inductive-reasoning activity to create classroom rules at the beginning of the school year. Students will not only observe these class rules willingly but also feel belonged to the learning community due to the ownership in creating these rules.

- $\quad$ Second is to build an academic atmosphere through supportive environment. In a cognitively supportive academic environment, teachers work hard to help students understand the subject matter through welldesigned and well-implemented lessons, positive classroom interaction, easy access to learning and information resources in the classrooms. At the same time, teachers motivate students by helping them 
develop the right attitude for learning, use persuasion when necessary, establish a concept of learning imperative in classrooms and challenge students to reach their highest potentials.

- $\quad$ Third is to build a positive social context through supportive environment. Minority students including African-American students learn better in a supportive social context. This supportive social context refers to positive teacher-student and student-student relationships (Irvine \& Armento, 2001; Ladson-Billings, 2005). Such a social context is created and exemplified through by the teacher through the display of fairness, respect, trust, caring, and non-favoritism in classrooms when interacting with students. Teachers must be good role-models and show consistency in order to establish a supportive social context to encourage students' participation and reduce frictions in classrooms. The result is a harmonious learning environment.

- $\quad$ Fourth is to build academic-engaged time through high expectations. Academic-engaged time is the time spent engaging students in actual learning activities (e.g., reading, completing math algorithms or any learning tasks without other incidents). Academic-engaged time is positively related to student learning outcomes (Konza, Grainger, Bradshaw, 2003). Maximize the time in academic-related tasks and reducing the time spent on other incidents (e.g., discipline issues) by creating productive classroom norms is essential for effective learning. Teachers must be committed to their student academic success through lesson planning for increasing academic-engaged time and reinforcing high academic standards while meet the different needs of students.

\section{A FINAL WORD}

Democratic education is to provide opportunities for all children to succeed (Bennet, 2003; Campbell, 2004; Fass, 1989). Education must foster the intellectual, personal, and social development of all students to their fullest potential. We believe that closing the persistent achievement gaps and enhancing the academic success of minority students, including African-American students, is of primary importance if the nation is to compete effectively in the globalized economy and world market places. This study examined the factors for the academic success of African-American pre-service teachers. The findings revealed that, in order to promote student academic success, it is crucial that teachers help students develop positive self-concepts including some necessary successful personal factors within supportive learning environments in addition to cognitive aspects to support student academic success. Good teachers teach responsibilities, confidence, and resiliency in addition to academic knowledge. Teachers have a moral obligation to engage their students in learning and allow them to be socially, personally, and academically successful and be productive citizens. Teachers can make a difference when we are willing to share time, love, hope and work hard with our students.

\section{AUTHOR INFORMATION}

Dr. Nan Li is Associate Professor at Claflin University. Dr. Li is currently managing three grant project (3.2 million) with 2.5 grant projected funded by U.S. Department of Education. Dr. Li has presented at international and national conferences, which include American Educational Research Association (AERA) and National Association for Multicultural Education (NAME) international conferences, for her research with the focus on academic success of minority students. Her recent publications include journal articles and book chapters that advocate promoting the academic success for minority students. E-mail: nli@claflin.edu

\section{REFERENCES}

1. Barrick, M. R. \& Mount, M. K. (1993). Autonomy as a moderator of the relationships between the big five personality dimensions and job performance. Journal of Applied Psychology, 78(1), 111-118.

2. Bennett, C. I. (2003). Comprehensive multicultural education: Theory and practice (5 ${ }^{\text {th }}$ Ed.). Boston, MA: Allyn and Bacon.

3. Campbell, D. E. (2004). Choosing democracy: A practical guide to multicultural education ( ${ }^{\mathrm{rd}}$ Ed.). Upper Saddle River, NJ: Merrill Prentice Hall.

4. Chiu, M. M., \& Khoo, L. (2005). Effects of resources, inequality, and privilege bias on achievement: Country, school, and student level analyses. American Educational Research Journal, 42(4), 575-603. 
5. Darling-Hammond, L. (2004). What happens to a dream deferred? The continued quest for equal educational opportunity. In J. A. Bank \& C. A. McGee Banks (Eds.), Handbook of Research on Multicultural Education (pp. 607-630). San Francisco, CA: Jossey-Bass.

6. Dillon, N. (2005). The Loss of Diversity. American School Board Journal, 192(12), 34-38.

7. Fass, P.S. (1989). Outside in: Minorities and the transformation of American education. New York: Oxford University Press.

8. Gollnick, D. M., \& Chinn, P. C. (2005). Multicultural education in a pluralistic society ( $7^{\text {th }}$ Ed.). Upper Saddle River, NJ: Merrill Prentice Hall.

9. Konza, D., Grainger, J., Bradshaw, K. (2003). Classroom management: A survival guide. Southbank Victoria, Australia: Thompson Social Science Press.

10. Lee, C. D., \& Slaughter-Defoe, D. T. (2004). Historical and sociocultural influences on African-American education. In J. A. Bank \& C. A. McGee Banks (Eds.), Handbook of Research on Multicultural Education (pp. 462-490). San Francisco, CA: Jossey-Bass.

11. Li, N. (2005). Speaking from the otherness: A new perspective on U.S. diversity and suggestions for educational equality. Multicultural Perspectives, 7(3), 36-41.

12. Merriam, S.B. (2001). Qualitative research and case study application in education. San Francisco, CA: Jossey-Bass Publishers.

13. National Assessment for Educational Progress. (2005). NAEP 2005 trends in academic progress (NCES 2009-479). National Center for Education Statistics, Institute of Education Sciences, U.S. Department of Education, Washington, D.C.

14. National Center for Education Statistics. (2005). The Condition of Education 2005, NCES 2005-094, Washington, DC: U.S. Government Printing Office.

15. Maslow, A.H. (1987). Motivation and Personality, 3rd edition, edited by Robert Frager, James Fadiman, and Ruth Cox. New York: Harper and Row.

16. Patton, M. Q. (2002). Qualitative research \& Evaluations $\left(3^{\text {rd }}\right)$. Thousand Oaks, CA: Sage Publications.

17. Ridgell, S. D., \& Lounsbury, J. W. (2004). Predicting academic success: general intelligence, Big Five personality traits, and work drive. College Student Journal, 38(4), 607-619.

18. Reigeluth, C.M. (2004). Educational systems design. In A. Kovalchik \& K. Dawson (Eds.), Education and Technology: An Encyclopedia. Santa Barbara, CA: ABC-Clio.

19. Scheuermann, B. (2000). Curricular and instructional recommendations for creating safe, effective, and nurturing school environments for all students. In L.M. Bullock \& R.A. Gabel (Ed.), Positive Academic and Behavioral Supports: Creating Safe, Effective, and Nurturing Schools for All Students. Norfolk, VA: Council for Children with Behavioral Disorders. (ERIC Document Reproduction Service No. ED457628).

20. U.S. Census Bureau. (2006). National Population Projections. Retrieved November 24, 2009, from http://www.census.gov/population/www/pop-profile/natproj.html.

21. Valentine, V. L. (2005). Editor's Note: Crisis in the Classroom. Crisis, 112(5), 2-2. 